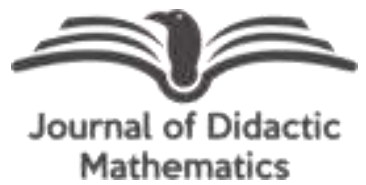

\title{
Penerapan model pembelajaran situation-based learning terhadap pemahaman matematis siswa kelas X SMA
}

\section{Beni Junedi*}

Universitas Bina Bangsa Banten, Jl. Raya Serang - Jakarta, KM. 03 No. 1B, Banten, Indonesia, 42124

\section{Ade Susanti}

Program Studi Pendidikan Matematika STKIP Insan Madani Airmolek, Jl. Jenderal Sudirman Tanah Tinggi Airmolek I, Pasir Penyu, Indragiri Hulu, Riau, Indonesia, 29352

*Corresponding Author: beni.junedi@binabangsa.ac.id

\begin{abstract}
The research aims to find out the students' mathematical understanding using situation-based learning model students of class X IPA, the type of research used is quasi-experimental design research, taking class X IPA 3 as an experimental class and class X IPA 2 as a control class. The technique used in this sampling is cluster random sampling. Research instruments in the form of tests to determine the level of mathematical understanding of students. The data obtained will be analyzed with the hypothesis test t-test. Hypothesis test results obtained a significant value $<0.05$ which is $0.049<0.05$. Based on these results it was concluded to reject $\mathrm{H}_{0}$ and accept $\mathrm{H}_{\mathrm{a}}$. This means the average student's mathematical understanding ability using the Situation-Based Learning model is better than the average student's mathematical understanding ability using conventional learning.
\end{abstract}

Historis Artikel:

Diterima: 7 Maret 2020

Direvisi: 14 Maret 2020

Disetujui: 2 April 2020

\section{Keywords:}

Mathematical

understanding ability, situation-based learning

Sitasi: Junedi, B., \& Susanti, A. (2020). Penerapan model pembelajaran situation-based learning terhadap pemahaman matematis siswa kelas X SMA. Journal of Didactic Mathematics, 1(1), 47-52. https://doi.org/10.34007/jdm.v1i1.159

\section{PENDAHULUAN}

Pemahaman Matematis adalah pengetahuan siswa terhadap konsep, prinsip, prosedur dan kemampuan siswa menggunakan strategi penyelesaian terhadap suatu masalah yang disajikan (Usman, 2017). Hal ini memberikan pengertian bahwa materi-materi yang diajarkan kepada siswa bukan hanya sebagai hafalan, namun diharapkan siswa dapat lebih mengerti akan konsep materi pelajaran itu sendiri (Deka, 2016). Pemahaman matematis merupakan dan tujuan dari suatu proses pembelajaran matematika. Pemahaman matematis sebagai suatu tujuan berarti suatu kemampuan memahami konsep, membedakan sejumlah konsep-konsep yang saling terpisah, serta kemampuan melakukan perhitungan secara bermakna pada situasi atau permasalahan-permasalahan yang lebih luas (Lely, 2017).

Berdasarkan hasil observasi diperoleh informasi bahwa pemahaman matematis siswa dalam pembelajaran matematika tergolong rendah, terlihat dari hasil rata-rata ulangan harian yang diperoleh pada tabel 1 berikut.

Tabel 1.Hasil Rata-Rata Ulangan Harian Siswa Kelas X-IPASMA Negeri 1 Pasir Penyu

\begin{tabular}{cccc}
\hline No & Kelas & n (Banyak Siswa) & Rata-Rata UH \\
\hline 1 & X IPA 1 & 30 & 66,28 \\
\hline 2 & X IPA 2 & 31 & 64,10 \\
\hline 3 & X IPA 3 & 31 & 57,63 \\
\hline 4 & X IPA 4 & 30 & 68,81 \\
\hline
\end{tabular}


Berdasarkan tabel di atas terlihat bahwa pemahaman matematis siswa tergolong rendah dengan tingkat ketercapain 64,2\%. Berdasarkan hasil pengamatan di dalam kelas diperoleh informasi bahwa permasalahan mendasar yang terlihat ketika proses pembelajaran adalah kurangnya keaktifan siswa dalam proses pembelajaran, tidak ada kekreatifan siswa untuk mencoba menulis kesimpulan dari penjelasan-penjelasan yang dijelaskan oleh guru. Hal ini dapat dilihat dari catatan yang hampir sama pada setiap siswa. Disamping itu siswa cenderung hanya menghapal konsep, tanpa mengetahui cara mengaplikasikan konsep tersebut, sehingga ketika ada soal-soal yang baru, siswa tidak mampu menyelesaikannya. Siswa hanya mampu menyelesaikan soal-soal yang sama persis dengan yang dicontohkan oleh guru. Permasalahan lainnya yang mempengaruhi pemahaman siswa adalah siswa enggan mencari informasi lebih lanjut tentang materi yang sudah dipelajari baik dari buku, internet atau mungkin bertanya kepada guru. Kurangnya rasa ingin tahu siswa untuk mengembangkan informasi yang sudah mereka peroleh dapat dilihat dari pertemuan berikutnya, yang mana ketika guru memberikan pertanyaan baru yang berkaitan dengan materi sebelumnya tidak ada siswa yang mampu menjawab dengan benar. Salah satu akibat dari pembelajaran tersebut diantaranya pengembangan kemampuan pemahaman matematis siswa tidak maksimal (Galih, 2018).

Berdasarkan permasalahan di atas, perlu solusi yang tepat untuk mengatasi gejala-gejala yang timbul dalam proses pembelajaran. Solusi yang tepat adalah dengan menerapkan model pembelajaran yang dapat meningkatkan rasa ingin tahu siswa tentang materi pelajaran, membangkitkan keaktifan siswa untuk bertanya, memantapkan pemahaman siswa tentang konsep dasar materi yang diajarkan, siswa bukan hanya sebagai pendengar, tetapi mereka yang dituntut aktif berbicara menyampaikan hal-hal yang meraka pahami. Model pembelajaran yang diduga dapat mengatasi permasalahan diatas adalah model pembelajaran Situation-Based Learning (SBL). Model pembelajaran SBL adalah salah satu model pembelajaran yang berpusat pada peserta didik, hal ini dikarenakan ada banyak hal yang dapat peserta didik pelajari dari banyak situasi di tempat dimana mereka belajar (Indah, Yuan, \& Mailizar, 2019). Model pembelajaran SBL adalah model pembelajaran berbasis situasi di mana guru mengkreasi sebuah situasi pembelajaran yang dapat memunculkan pertanyaan dari siswa dan siswa memecahkan permasalahan yang dibangunnya sendiri (Aqilah, Isrok'atun, \& Jayadinata, 2017). Dengan penerapan situation based learning pembelajaran matematika akan lebih interaktif, siswa akan berpartipasi aktif di dalam proses pembelajaran karena materi pembelajaran dihubungkan langsung dengan situasi dan konteks permasalahan sehari-hari. Partisipasi siswa dalam bentuk memunculkan pertanyaan yang terkait dengan situasi atau konteks dari suatu permasalahan.

Model pembelajaran SBL merupakan model pembelajaran konstruktivistik yaitu model pembelajaran yang menghubungkan konsep matematika yang bersifat abstrak ke situasi nyata yang terdapat dalam kehidupan sehari-hari. Model pembelajaran ini didukung oleh adanya teori Ausubel yang mengatakan bahwa pembelajaran bermakna merupakan suatu proses mengaitkan informasi baru pada konsep-konsep relevan yang terdapat dalam struktur kognitif seseorang, Burhanuddin (dalam Rahmah, 2013). Situation based learning (SBL) dalam pelaksanaanya terdiri dari 4 tahapan yaitu creating mathematical situations, posing mathematical problem, solving mathematical problem, applying mathematics (Sowanto, 2019). Creating mathematical situations adalah prasyarat. Posing mathematical problem adalah inti, sedangkan solving mathematical problem adalah tujuan, sementara applying mathematics adalah penerapan proses pembelajaran terhadap situasi baru (Isrok'atun \& Tiurlina, 2014). Tujuan dari model pembelajaran SBL adalah untuk mengembangkan kemampuan siswa dalam problem posing, problem understanding, dan problem solving dari sudut pandang matematika (Intan, Isrok'atun, \& Diah, 2016). Secara umum pembelajaran Situation based learning bertujuan untuk mengembangkan kemampuan siswa dalam memahami serta menyelesaikan suatu konteks atau situasi materi pembelajaran berdasarkan permasalahan-permasalahan yang dimunculkan dari situsi yang diberikan. Situasi dirancang semanarik mungkin sehingga memunculkan pertanyaan pertanyaan interaktif dari siswa. 
Penerapan model pembelajaran situation-based learning terhadap...

\section{METODE}

Penelitian yang dilaksanakan adalah penelitian eksperimen (experiment research) yang bertujuan untuk menyelidiki kemungkinan saling hubungan sebab-akibat dengan cara mengenakan kepada satu atau lebih kelompok eksperimental satu atau lebih kondisi perlakuan dan memperbandingkan hasilnya dengan satu atau lebih kelompok kontrol yang tidak dikenai kondisi perlakuan (Sumadi, 2004:88).Sebab akibat yang dimaksudkan adalah pengaruh model pembelajaran Situation-Based Learning (SBL) terhadap kemampuan pemahaman matematis siswa kelas X IPA SMA N 1 Pasir Penyu.Adapun rancangan penelitian yang digunakan adalah Randomized Subject Posttes Only Control Group Design (Darmadi, 2013:221).

Tabel 2. Desain Penelitian

\begin{tabular}{cccc}
\hline & Group & Variabel Terikat & Postest \\
\hline $\mathrm{R}$ & Eksperimen & $\mathrm{X}$ & $Y_{2}$ \\
\hline $\mathrm{R}$ & Kontrol & - & $Y_{2}$
\end{tabular}

Keterangan:

$\mathrm{R}$ : Random

$\mathrm{X}$ : Perlakuan dengan model Situation-Based Learning (SBL).

$\mathrm{Y}_{2}$ : Tes kemampuan pemahaman matematis siswa

Instumen penelitian berupa tes pemahaman matematis siswa yang diberikan diakhir penelitian, sedangkan teknik analisis data menggunakan uji t dengan uji normalitas serta uji homogenitas sebagai uji prasyarat.

\section{HASIL DAN PEMBAHASAN}

Sebagai prasyarat uji t dilakukan terlebih dahulu uji normalitas dan uji homogenitas. Uji normalitas dilakukan untuk mengetahui apakah sampel berdistribusi normal atau tidak. Dari analisis data diperoleh hasil seperti pada tabel 3 berikut.

Tabel 3.Hasil Perhitungan Uji Normalitas Kelas Sampel

\begin{tabular}{lcc}
\hline Sampel & Nilai Sig & Keterangan \\
\hline Eksperimen & 0,083 & Normal \\
\hline Kontrol & 0,200 & Normal \\
\hline
\end{tabular}

Dari tabel 3 diketahui bahwa nilai Sig kelas eksperimen dan kelas kontrol lebih besar dari nilai $\alpha(0,05)$, berdasarkan kriteria uji normalitas jika nilai signifikan besar dari $0,05(\alpha)$, maka data tersebut berdistribusi normal. Dari hasil analisis data, diperoleh nilai signifikan 0,083 $>0,05$ dan $0,200>0,05$, maka data berdistribusi normal.

Uji homogenitas bertujuan untuk mengetahui apakah kedua kelas sampel mempunyai varians yang homogen atau tidak, pengujian dilakukan menggunakan software SPSS. Hasil output SPSS uji homegenitas dapat dilihat pada tabel berikut.

Tabel 4.Hasil Perhitungan Uji Homogenitas Kelas Sampel

\begin{tabular}{lccc} 
& Nilai Sig & Nilai $\alpha$ & Keterangan \\
\hline Eksperimen & 0,765 & 0,05 & Homogen \\
\hline Kontrol & & & \\
\hline
\end{tabular}


Dari hasil di atas, terlihat bahwa nilai signifikan yang diperoleh adalah 0,765 lebih besar dari nilai $\alpha(0,05)$. Maka berdasarkan kriteria uji homogenitas, diperoleh kesimpulan bahwa kedua kelas sampel memiliki varians yang homogen.

Berdasarkan hasil uji prasyarat, diperoleh data bahwa kelas sampel berdistribusi normal dan memiliki varian yang homogen. Selanjutnya dilakukan pengujian hipotesis, dengan menggunakan Uji-t. Uji ini merupakan uji terakhir dalam menganalisa data hasil penelitian yang bertujuan untuk mengetahui ada tidak nya pengaruh model pembelajaran Situation-Based Learning (SBL) terhadap kemampuan pemahaman matematis siswa kelas X IPA SMA Negeri 1 Pasir Penyu. Dari hasil output SPSS, diperoleh nilai signifikansi $<0,05(0,049<0,05)$. Berdasarkan pengujian hipotesis, dapat disimpulkan bahwa terima $\mathrm{H}_{2}$ dan $\mathrm{H}_{\mathrm{o}}$ ditolak artinya rata-rata kemampuan pemahaman matematis siswa dengan menggunakan model pembelajaran Situation-Based Learning (SBL) lebih baik dari pada rata-rata kemampuan pemahaman matematis siswa dengan menggunakan pembelajaran konvensional (biasa).

Hasil dari penelitian menyatakan bahwa rata-rata kemampuan pemahaman matematis siswa dengan menggunakan model pembelajaran Situation-Based Learning (SBL) lebih baik dari pada ratarata kemampuan pemahaman matematis siswa dengan menggunakan pembelajaran konvensional (biasa). Secara umum siswa yang mendapat pembelajaran SBL mengalami peningkatan KBM yang lebih tinggi daripada siswa yang mendapat pembelajaran konvensional (Ratnasari, 2019). Model pembelajaran ini merupakan salah satu model pembelajaran yang efektif karena siswa akan lebih mudah mengingat materi ajar yang berkaitan langsung dengan kehidupan sehari-hari. Selain itu, penerapan model ini juga melatih keaktifan siswa dalam proses pembelajaran. Berikut akan dipaparkan jawaban dari tes akhir yang diberikan pada kelas sampel untuk pemahaman matematis siswa dalam bentuk indikator-indikator pemahaman matematis siswa:

\section{Membandingkan dan membedakan konsep-konsep}

Kemampuan pemahaman matematis siswa pada indikator ini, dapat dilihat dari hasil tes siswa yang mana siswa sudah bisa membedakan rumus antara aturan sinus dan kosinus. Hal ini terlihat pada adanya perbedaan jawaban siswa pada kelas eksperimen dan kelas kontrol. Ini menandakan bahwa kemampuan membandingkan dan membedakan konsep-konsep matematika pada kelas eksperimen lebih baik dari pada kelas kontrol. Siswa pada kelas kontrol hanya menghafal konsep, sementara jawaban siswa pada kelas eksperimen dijelaskan dengan gambar dan dilengkapi dengan rumus sesuai dengan jawaban yang diinginkan. Indikator membandingkan dan membedakan konsep-konsep terdapat pada soal Berikut.

$$
\begin{aligned}
& \text { Bagaimana proses penemuan konsep aturan sinus } \frac{a}{\sin A}=\frac{b}{\sin B}=\frac{c}{\sin c} \text { dan } \\
& \text { aturan kosinus: } \boldsymbol{a}^{2}=\boldsymbol{c}^{2}+\boldsymbol{b}^{2}-2 \boldsymbol{b c} \cos \boldsymbol{A}, \boldsymbol{b}^{2}=\boldsymbol{a}^{2}+\boldsymbol{c}^{2}-2 \boldsymbol{a c} \cos \boldsymbol{B}, \boldsymbol{c}^{2}=\boldsymbol{a}^{2}+\boldsymbol{b}^{2}-2 \boldsymbol{a b} \cos \boldsymbol{C} \\
& \text { dan jelaskan perbedaan kedua aturan tersebut? }
\end{aligned}
$$

Dengan menggunakan model pembelajaran Situation-Based Learning (SBL) siswa mengingat dengan mudah konsep dari aturan sinus dan kosinus karena konsep yang didapat berasal dari situasi yang disajikan dalam proses pembelajaran ditemui dalam kehidupan. Hal ini dikerenakan pada kelas eksperimen pembelajarannya menggunakan model pembelajaran Situation-Based Learning (SBL) yang menuntut siswa untuk dapat memahami dan membedakan konsep matematika secara lebih menarik karena penyajian materi ajarnya berkaitan langsung dengan apa yang siswa lihat pada kehidupun sehari-hari. Situation-Based Learning (SBL) menuntut siswa mengkostruksi pengetahuan yang dimiliki sehingga muncul konflik kognitif yang memungkinkan siswa tersebut memunculkan pertanya pertanyaan terhadap situasi yang sudah di rancang dengan baik oleh guru.

\section{Mengaplikasikan konsep atau algoritma pada pemecahan masalah}

Mengaplikasikan konsep atau algoritma pada pemecahan masalah dapat ditinjau dari jawaban siswa pada soal berikut. 
Penerapan model pembelajaran situation-based learning terhadap...

Pada segitiga $P Q R$ diketahui $\angle P Q R=1200$, panjang sisi $p=10 \mathrm{~cm}$, sisi $r=12 \mathrm{~cm}$. Hitunglah panjang sisi q!

Jawaban siswa pada kelas eksperimen bervariasi tetapi mengacu pada satu tujuan, dapat dibedakan secara jelas pengaplikasian konsep pada kelas eksperimen dijabarkan secara lebih jelas, langkah-langkah penyelesaian teratur, menggambarkan ilustrasi dari soal sehingga hasil akhir yang didapat sesuai dengan yang diharapkan. Sedangkan siswa kelas kontrol, kurang mampu mengaplikasikan konsep sehingga penggunaan rumus dalam penyelesaian masalah kurang tepat, sehingga ketika diberi soal-soal baru, siswa kesulitan untuk menyelesaikannya. Dari jawaban siswa di atas dapat disimpulkan bahwa pada indikator mengaplikasikan konsep atau algoritma pada pemecahan masalah di kelas eksperimen lebih baik dari mengaplikasikan konsep atau algoritma pada pemecahan masalah di kelas kontrol. Hal ini dikarenakan dalam proses pembelajaran dengan menggunakan model pembelajaran Situation-Based Learning (SBL) siswa menyimpulkan sendiri jawaban dari pertayaan-pertanyaan yang muncul ketika situasi diberikan dan guru hanya menambahkan jawaban yang dinilai sudah tepat.

\section{Menggunakan dan memanfaatkan serta memilih prosedur atau operasi tertentu}

Deskripsi indikator mengunakan dan memanfaatkan serta memilih prosedur atau operasi tertentu terdapat pada soal berikut.

Diketahui segitiga $A B C$ dengan panjang sisi $A B=9 \mathrm{~cm}, A C=7 \mathrm{~cm}$, dan $B C=8 \mathrm{~cm}$. Tentukan nilai $\sin B$ ?

Pada kelas eksprimen dan kelas kontrol menggunakan dan memanfaatkan serta memilih prosedur atau operasi tertentu dapat dilihat dari jawaban siswa pada soal di atas berikut ini. siswa pada kelas eksperimen dan kelas kontrol. Jawaban siswa pada kelas eksperimen dalam menjawab soal di atas, terlihat bahwa siswa sudah dapat mengingat, memahami serta dapat memilih dan memanfaatkan prosedur atau operasi tertentu untuk menyelesaikan soal tersebut secara terstruktur dan jelas sesuai prosedur. Kemampuan ini didasari oleh kemampuan siswa dalam melakukan keterkaitan antara konsep yang sudah dipelajari sebelumnya. Pada kelas kontrol, siswa masih kurang mampu dalam melakukan keterkaitan antar konsep. Proses berfikir siswa sudah terarah namun belum prosedural, sehingga hasil akhir yang diinginkan belum sesuai dengan jawaban yang seharusnya. Proses pembelajaran SBL dapat diterapkan melalui serangkaian bahan desain berdasarkan pembelajaran berbasis situasi sehingga siswa dapat mengembangkan kreativitas dan memikirkan produktivitas lebih lanjut. Peran guru di sini hanyalah sebagai motivator dan fasilitator (Ardagh \& Borges, 2016).

\section{KESIMPULAN}

Berdasarkan hasil penelitian disimpulkan bahwa model pembelajaran (Situation-Based Learning) SBL ini mempunyai dampak yang signifikan terhadap kemampuan pemahaman konsep matematis siswa kelas X IPA SMA N 1 Pasir Penyu. $\mathrm{H}_{o}$ ditolak dan terima $\mathrm{H}_{\mathrm{a}}$, artinya rata-rata kemampuan pemahaman matematis siswa dengan menggunakan model pembelajaran SituationBased Learning (SBL) lebih baik dari pada rata-rata kemampuan pemahaman matematis siswa dengan menggunakan pembelajaran konvensional (biasa).

\section{DAFTAR PUSTAKA}

Sari, D. P., Nurochmah., Haryadi., \& Syaiturjim. (2016). Meningkatkan kemampuan pemahaman matematis melalui pendekatan pembelajaran student teams achivement division. Jurnal Riset Pendidikan Matematika, 3(1), 16-22.

Kurniadi, G., \& Purwaningrum, J. P. (2018). Kemampuan pemahaman matematis siswa melalui discovery learning berbantuan asesmen hands on activities. ANARGYA: Jurnal Ilmiah Pendidikan Matematika, 1(1), 8-13. https://doi.org/10.24176/anargya.v1i1.2463

Darmadi, H. (2013). Metode penelitian pendidikan dan sosial. Bandung: Alfabeta. 
Lestari, I., Andinny, Y., \& Mailizar. (2019). Pengaruh model pembelajaran situation based learning dan kemandirian belajar terhadap kemampuan pemecahan masalah matematis. JNPM (Junal Nasional Pendidikan Matematika), 3(1), 95-108. http://dx.doi.org/10.33603/jnpm.v3i1.1748

Larawati, I., Isrok'atun., \& Gusrayani, D. (2016), Penerapan model pada materi sifat dan jaringjaring bangun ruang sederhana di kelas IV SDN Paseh 1 Sumedang. Jurnal Pena Imiah, 1(1), 71-80. https://doi.org/10.23819/pi.v1i1.2933

Syarifah, L. L. (2017). Analisis kemampuan pemahaman matematis pada mata kuliah pembelajaran matematika SMA II, JPPM (Jurnal Penelitian dan Pembelajaran Matematika), 10(2), 57-71. https://dx.doi.org/10.30870/ippm.v10i2.2031

Sowanto. (2019). Meningkatkan kemampuan self-efficacy siswa smp melalui situation based learning berbantuan program geometer's sketchpad (GSP). SUPERMAT Jurnal Pendidikan Matematika, 3(1), 23-33. https://doi.org/10.33627/sm.v3i1.172

Suryabrata, S. (2004). Metodologi penelitian. Jakarta: PT RajaGrafindo Persada.

Alan, U. F., \& Afriansyah, E. A, (2017). Kemampuan pemahaman matematis siswa melalui model pembelajaran auditory intellectualy repetition dan problem based learning. JPM: Jurnal Pendidikan Matematika, 11(1), 68-77. https://doi.org/10.22342/jpm.11.1.3890.67-78

Ratnasari, S. A. (2019). Situation-based-learning (SBL) untuk meningkatkan kemampuan berpikir kritis matematis siswa SMP. Jurnal Edukasi Sebelas April, 3(1), 21-31.

Rahmah, N. (2013). Belajar bermakna Ausubel. Al-khwarizmi: Junal Pendidikan Matematika dan Ilmu Pengetahuan Alam, 1(1), 43-48. https://doi.org/10.24256/jpmipa.v1i1.54

Isrok'atun., \& Tiurlina. (2014). Situation-based-learning (SBL) untuk meningkatkan kemampuan creative problem solving matematis siswa SD. Mimbar Sekolah Dasar, 1(2), 209-216. https://doi.org/10.17509/mimbar-sd.v1i2.885

Aqilah, B., Isrok'atun., \& Jayadinata, A. K. (2017). Situation-based learning dalam upaya meningkatkan kemampuan creative problem solving matematis siswa pada materi bilangan bulat. Jurnal Pena Ilmiah, 2(1), 1001-1010. https://doi.org/10.17509/jpi.v2i1.11248

Ardagh, M., \& Borges, K. (2016). Situaton-based learning in elementary school: Enhancement of students' mathematical creative problem solving ability. International Journal of Science Arts and Commerce, 1(6), 60-70. 